\title{
Article
}

Mycosphere

\section{DNA barcoding as a tool for identification of plasmodia and sclerotia of myxomycetes (Myxogastria) appearing in moist chamber cultures}

\section{Shchepin ON ${ }^{1,2 *}$, Dagamac $\mathbf{N H}^{2}$, Sanchez OM${ }^{2}$, Novozhilov YK ${ }^{1}$, Schnittler $\mathbf{M}^{2}$, Zemlyanskaya IV $^{3}$}

\author{
${ }^{1}$ Komarov Botanical Institute of the Russian Academy of Sciences, Laboratory of Systematics and Geography of Fungi, \\ Prof. Popov Street 2, 197376 St. Petersburg, Russia \\ ${ }^{2}$ Institute of Botany and Landscape Ecology, Ernst Moritz Arndt University Greifswald, Soldmannstr. 15, D-17487 \\ Greifswald, Germany \\ ${ }^{3}$ Volgograd State Medical University, Pavshikh Bortsov Square 1, 400131 Volgograd, Russia
}

Shchepin ON, Dagamac NH, Sanchez OM, Novozhilov YK, Schnittler M, Zemlyanskaya IV 2017 - DNA barcoding as a tool for identification of plasmodia and sclerotia of myxomycetes (Myxogastria) appearing in moist chamber cultures. Mycosphere 8(10), 1904-1913, Doi 10.5943/mycosphere/8/10/13

\begin{abstract}
Moist chamber culture experiments are one of the basic methods of detection of myxomycete diversity that is usually employed to complement field datasets based on fruit bodies (sporocarps). However, often a large fraction of plasmodia that appear in moist chamber cultures does not yield sporocarps that can be determined to species based on morphological traits. Instead, plasmodia convert to a dormant stage called sclerotium. Both structures essentially lack taxonomically valuable morphological characters, preventing assignment to a species. Here we report the results of application of DNA barcoding as a method of taxonomical identification of plasmodia and sclerotia that develop in moist chamber cultures. The first ca. $600 \mathrm{bp}$ of $18 \mathrm{~S}$ rRNA gene were successfully amplified for 38 sclerotium and 32 plasmodium samples. Comparison to a large collection of reference sequences and phylogenetic analysis allowed identifying sequences up to species (45), genus (15) or order (10) following several formal criteria. Additionally four partial EF1A gene sequences were obtained, demonstrating that single-copy nuclear genes can also be easily amplified from plasmodia and sclerotia. The outlined methodology could facilitate future studies of myxomycete diversity and ecology based on moist chamber cultures, effectively increasing diversity estimates.
\end{abstract}

Key words - 18S rRNA - Amoebozoa - hidden diversity - molecular taxonomy - plasmodial slime molds - SSU - substrates

\section{Introduction}

Plasmodial slime molds (Myxomycetes or Myxogastria) are spore-forming amoeboid protists that occur in almost any terrestrial ecosystem (Stephenson et al. 2008, Novozhilov et al. 2017a, Schnittler et al. 2017a). In their typical life cycle two microscopic uninucleate myxamoebae fuse to form distinctive multinucleate plasmodium that finally yields fruiting bodies (sporocarps) with complex morphology. Virtually all hitherto published diversity studies of myxomycetes are based on the occurrences of sporocarps and their morphological determination. Since it is impossible to 
detect the entire species diversity within one or several field surveys, especially in tropical forests where sporocarps occur very rarely, moist chamber cultures are usually employed to complement field datasets. With this approach, used first by Gilbert \& Martin (1933) and further developed by Camp (1936), small pieces of different substrates collected in the field (bark, dead wood etc.) are placed into Petri-dishes on several layers of wet filter paper and incubated for several weeks or months. Usually in most of the cultures one or several plasmodia appear, but many of them turn into a rigid dormant stage called sclerotium instead of producing sporocarps. Even additional feeding with an oatmeal and treatment with different moisture regimes often do not help in such cases. For example, in an extensive survey of myxomycete biota of monsoon tropical forests in southern Vietnam (Novozhilov et al. 2017b) more than one third of all moist chamber records represented non-fruiting plasmodia that finally formed sclerotia. Since plasmodia and sclerotia do not possess enough morphological traits for species determination, the resulting diversity seems to be significantly underestimated in moist chamber culture experiments.

Recent advances in developing DNA barcodes for myxomycetes could help to overcome this problem (Borg Dahl et al. 2017, Schnittler et al. 2017b). The first ca. 600 bp of the 18S rRNA gene are free of introns and are variable enough for a species-level determination. Although no universal primers exist for the whole group, this fragment can be easily amplified in most of the dark-spored myxomycetes using the single primer pair (S1/SU19R, Fiore-Donno et al. 2012). The aim of the current study was to test DNA barcoding as a method of taxonomic assignment for plasmodia and sclerotia that developed in moist chamber cultures.

\section{Materials \& Methods}

\section{DNA isolation and sequencing}

Small fragments of sclerotia that developed from plasmodia of undetermined species were isolated into $2 \mu 1$ microtubes using sterile forceps directly from moist chamber cultures that were set up with pieces of bark or leaf litter collected in different regions (Table 1). The resulting 52 samples were frozen at $-20{ }^{\circ} \mathrm{C}$ and crushed using a TissueLyser LT homogenizer (QIAGEN) equipped with a steel ball. Alternatively, 65 active plasmodia were scratched from the surface of the substrates using a sterile scalpel, placed into $1.5 \mu \mathrm{l}$ microtubes with $200 \mu \mathrm{l}$ of PBS buffer and homogenized using plastic pestle immediately before DNA extraction. DNA was extracted with Proba-GS DNA purification kit (DNK-Tekhnologia) or E.Z.N.A. Plant DNA Kit (Omega Bio-Tek) according to the manufacturer's protocols. The first part of the 18S rRNA gene was amplified using the primers S1/SU19R (Fiore-Donno et al. 2012) and BioMaster HS-qPCR kit (Diaem) or Bioline MyTaq Plant PCR Kit. PCR program included 40 cycles with annealing temperature $56{ }^{\circ} \mathrm{C}$. To check the availability of single-copy nuclear genes, for several samples a $750 \mathrm{bp}$ fragment of EF1A gene was amplified using the primer pair PB1F/PB1R (Novozhilov et al. 2014) with annealing temperature $65.4{ }^{\circ} \mathrm{C}$ and 40 amplification cycles. Amplicons were purified using diaGene PCR purification kit (Diaem) and sequenced using the Big Dye Terminator v3.1 Cycle Sequencing Kit (Thermo Fisher Scientific) on an ABI 3130 sequencer (Applied Biosystems). All sequences were checked for base-calling errors in BioEdit 7.2.5 (Hall 1999) and submitted to GenBank.

Table 1 Moist chamber cultures that produced plasmodia and sclerotia used in this study.

\begin{tabular}{|c|c|c|c|c|c|}
\hline $\begin{array}{l}\text { Moist } \\
\text { chamber }\end{array}$ & Region & Locality description & Substrate & Lat., $\mathbf{N}$ & Long., $\mathrm{E}$ \\
\hline 32002 & Russia, Leningrad region & $\begin{array}{l}\text { Old oak plantations in Alexandrovskiy } \\
\text { park }\end{array}$ & Bark of Quercus robur & 59.4390 & 30.2228 \\
\hline $\begin{array}{l}31496,31501 \\
31502\end{array}$ & Russia, Volgograd region & $\begin{array}{l}\text { Oak forest in Volga-Akhtuba } \\
\text { bottomland }\end{array}$ & $\begin{array}{l}\text { Bark of Quercus } \\
\text { petraea }\end{array}$ & 48.3915 & 44.4123 \\
\hline $\begin{array}{l}31519,31523 \\
31524\end{array}$ & Russia, Volgograd region & $\begin{array}{l}\text { Oak forest in Volga-Akhtuba } \\
\text { bottomland }\end{array}$ & Bark of $Q$. robur & 48.4208 & 44.3891 \\
\hline 31546 & Russia, Volgograd region & $\begin{array}{l}\text { Oak forest in Volga-Akhtuba } \\
\text { bottomland }\end{array}$ & Bark of $Q$. robur & 48.3836 & 44.5165 \\
\hline 31621 & Russia, Volgograd region & $\begin{array}{l}\text { Oak forest in Volga-Akhtuba } \\
\text { bottomland }\end{array}$ & Bark of $Q$. robur & 48.3509 & 44.3959 \\
\hline
\end{tabular}


Table 1 Continued.

\begin{tabular}{|c|c|c|c|c|c|}
\hline $\begin{array}{l}\text { Moist } \\
\text { chamber }\end{array}$ & Region & Locality description & Substrate & Lat., $\mathbf{N}$ & Long., $\mathbf{E}$ \\
\hline 31686,31691 & Russia, Volgograd region & $\begin{array}{l}\text { Oak forest in Volga-Akhtuba } \\
\text { bottomland }\end{array}$ & Bark of $Q$. robur & 48.4220 & 44.3675 \\
\hline 31748 & Russia, Volgograd region & $\begin{array}{l}\text { Oak forest in Volga-Akhtuba } \\
\text { bottomland }\end{array}$ & Bark of $Q$. robur & 48.3484 & 44.4477 \\
\hline 31810 & Russia, Volgograd region & $\begin{array}{l}\text { Oak forest in Volga-Akhtuba } \\
\text { bottomland }\end{array}$ & Bark of $Q$. robur & 48.4201 & 44.4125 \\
\hline 32024, 32027 & Russia, Volgograd region & $\begin{array}{l}\text { Oak forest in Volga-Akhtuba } \\
\text { bottomland }\end{array}$ & Bark of $Q$. robur & 48.2949 & 45.0315 \\
\hline 32042,32058 & Russia, Volgograd region & $\begin{array}{l}\text { Oak forest in Volga-Akhtuba } \\
\text { bottomland }\end{array}$ & Leaf litter of $Q$. robur & 48.3093 & 45.0762 \\
\hline 31902 & Russia, Volgograd region & $\begin{array}{l}\text { Oak forest in the Chapurnikovskaya } \\
\text { ravine }\end{array}$ & Leaf litter of $Q$. robur & 48.2902 & 44.2954 \\
\hline 31582,31577 & Russia, Volgograd region & $\begin{array}{l}\text { Oak forest with elm in Volga-Akhtuba } \\
\text { bottomland }\end{array}$ & Bark of $Q$. robur & 48.3462 & 44.4948 \\
\hline 31789, 31791 & Russia, Volgograd region & $\begin{array}{l}\text { Oak forest with elm in Volga-Akhtuba } \\
\text { bottomland }\end{array}$ & Bark of $Q$. robur & 48.3729 & 44.5139 \\
\hline $\begin{array}{l}31565,31558 \\
31560\end{array}$ & Russia, Volgograd region & $\begin{array}{l}\text { Oak forest with maple and ash-tree in } \\
\text { Volga-Akhtuba bottomland }\end{array}$ & Bark of $Q$. robur & 48.3157 & 44.4484 \\
\hline 31569 & Russia, Volgograd region & $\begin{array}{l}\text { Oak forest with maple and ash-tree in } \\
\text { Volga-Akhtuba bottomland }\end{array}$ & Leaf litter of $Q$. robur & 48.3157 & 44.4484 \\
\hline 40262,40297 & $\begin{array}{l}\text { Russia, Republic of } \\
\text { Crimea }\end{array}$ & Open xerophilous mixed forest & Bark of $Q$. petraea & 44.4941 & 34.5407 \\
\hline 40419 & $\begin{array}{l}\text { Russia, Republic of } \\
\text { Crimea }\end{array}$ & Open xerophilous mixed forest & Bark of $Q$. petraea & 44.5124 & 34.5658 \\
\hline 40361,40379 & $\begin{array}{l}\text { Russia, Republic of } \\
\text { Crimea }\end{array}$ & Xerophilous oak forest & Bark of $Q$. petraea & 44.5128 & 34.5706 \\
\hline 37495 & $\begin{array}{l}\text { Vietnam, Lam Dong } \\
\text { prov. }\end{array}$ & $\begin{array}{l}\text { Middle mountain evergreen forest } \\
\text { with Fagaceae }\end{array}$ & Leaf litter of Fagaceae & 12.1853 & 108.6780 \\
\hline 37171, 37174 & $\begin{array}{l}\text { Vietnam, Lam Dong } \\
\text { prov. }\end{array}$ & $\begin{array}{l}\text { Middle mountain evergreen forest } \\
\text { with Fagaceae }\end{array}$ & $\begin{array}{l}\text { Bark of Keteleeria } \\
\text { evelyniana }\end{array}$ & 12.1357 & 108.6456 \\
\hline 37191 & $\begin{array}{l}\text { Vietnam, Lam Dong } \\
\text { province }\end{array}$ & $\begin{array}{l}\text { High mountain evergreen cloudy } \\
\text { forest with Fagaceae }\end{array}$ & $\begin{array}{l}\text { Bark of Nageria } \\
\text { wallichiana }\end{array}$ & 12.1866 & 108.4175 \\
\hline DN26 & Vietnam, Da Nang & Plantation forest patch & Aerial leaf litter & 16.0050 & 108.2633 \\
\hline DN89 & Vietnam, Da Nang & Plantation forest patch & Ground leaf litter & 16.0050 & 108.2633 \\
\hline HA05 & $\begin{array}{l}\text { Vietnam, BaVi National } \\
\text { Park, Hanoi }\end{array}$ & Deciduous moist lowland forest & Aerial leaf litter & 21.0950 & 105.4006 \\
\hline $\begin{array}{l}\text { HA52, HA53, } \\
\text { HA54, HA55, } \\
\text { HA56 }\end{array}$ & $\begin{array}{l}\text { Vietnam, BaVi National } \\
\text { Park, Hanoi }\end{array}$ & Deciduous moist lowland forest & Ground leaf litter & 21.0950 & 105.4006 \\
\hline НА78, НА89 & $\begin{array}{l}\text { Vietnam, BaVi National } \\
\text { Park, Hanoi }\end{array}$ & $\begin{array}{l}\text { Small forest patch heading to the } \\
\text { butterfly garden }\end{array}$ & Ground leaf litter & 21.0950 & 105.4011 \\
\hline HA17 & $\begin{array}{l}\text { Vietnam, BaVi National } \\
\text { Park, Hanoi }\end{array}$ & $\begin{array}{l}\text { Closed canopy lowland forest with } \\
\text { stairs near the flowing stream }\end{array}$ & Aerial leaf litter & 21.0958 & 105.4042 \\
\hline НА33, НА37 & $\begin{array}{l}\text { Vietnam, BaVi National } \\
\text { Park, Hanoi }\end{array}$ & $\begin{array}{l}\text { The open forest patch along the road } \\
\text { with artificial pine forest }\end{array}$ & Aerial leaf litter & 21.0969 & 105.4067 \\
\hline $\begin{array}{l}\text { TH93, TH95, } \\
\text { TH96 }\end{array}$ & $\begin{array}{l}\text { Vietnam, Thai Nguyen } \\
\text { Province }\end{array}$ & Forest fragment along the highway & Ground leaf litter & 21.5858 & 105.7008 \\
\hline $\begin{array}{l}\text { TH81, TH84, } \\
\text { TH87, TH88 }\end{array}$ & $\begin{array}{l}\text { Vietnam, Thai Nguyen } \\
\text { Province }\end{array}$ & Forest patch along the road & Ground leaf litter & 21.5911 & 105.6908 \\
\hline TH39 & $\begin{array}{l}\text { Vietnam, Thai Nguyen } \\
\text { Province }\end{array}$ & Plantation forest in lowland area & Aerial leaf litter & 21.5953 & 105.6847 \\
\hline ТН76, ТН79 & $\begin{array}{l}\text { Vietnam, Thai Nguyen } \\
\text { Province }\end{array}$ & Plantation forest in lowland area & Ground leaf litter & 21.5953 & 105.6847 \\
\hline $\begin{array}{l}\text { ТH61, ТН64, } \\
\text { ТН65, ТН67, } \\
\text { ТН69 }\end{array}$ & $\begin{array}{l}\text { Vietnam, Thai Nguyen } \\
\text { Province }\end{array}$ & $\begin{array}{l}\text { Closed forest area of plantation forest } \\
\text { between agricultural meadows }\end{array}$ & Ground leaf litter & 21.5967 & 105.6856 \\
\hline $\begin{array}{l}\text { TH52, ТH57, } \\
\text { TH58, }\end{array}$ & $\begin{array}{l}\text { Vietnam, Thai Nguyen } \\
\text { Province }\end{array}$ & $\begin{array}{l}\text { Open forest fragments on protected } \\
\text { agricultural site }\end{array}$ & Ground leaf litter & 21.5989 & 105.6867 \\
\hline
\end{tabular}

\section{Sequence-based identification}

Two methods were applied for a taxonomic assignment of the resulting 70 partial $18 \mathrm{~S}$ rRNA gene sequences obtained from sclerotia and plasmodia: similarity-based and phylogeny-based.

For the similarity-based taxonomic assignment the sequences were compared to the reference sequence collection from Borg Dahl et al. (2017) updated with new sequences using the semiglobal alignment algorithm (--usearch_global command) in VSEARCH 2.5.2 software (Rognes et al. 2016). A match to the reference sequence was considered sufficient for a species-level 
determination of the unknown sequence if their similarity was $\geq 99.1 \%$, as was suggested by Borg Dahl et al. (2017).

A phylogeny-based assignment was performed to assign unknown sequences to genus or higher taxonomic ranks, if no sufficient similarity to a fruit body-derived sequence from the reference database was found. For this, 48 reference sequences (including 18 that were best matches among references) representing all major clades of dark-spored myxomycetes were chosen based on previously published phylogenies (Fiore-Donno et al. 2010, 2012) and aligned with 70 new sequences with MAFFT online service (Katoh et al. 2017) using the E-INS-i algorithm. A Maximum Likelihood (ML) phylogeny was built with IQ-TREE 1.5.5 (Nguyen et al. 2015) with 1000 ultrafast (UF) bootstrap replicates (Minh et al. 2013) using the alignment with 892 positions. $\mathrm{TNe}+\mathrm{R} 4$ was chosen by ModelFinder (Kalyaanamoorthy et al. 2017) as an optimal substitution model according to the Bayesian information criterion. The resulting ML tree was rooted with members of Meriderma based on the phylogeny published in Fiore-Donno et al. (2012). To achieve an assignment to genus the following criteria were used: 1) the sequence in question should show at least $90 \%$ similarity to a reference sequence of a species from this genus and 2) it should branch within a clade containing only members of this genus with $\geq 95 \%$ UF bootstrap support. For assignment to a higher-level taxon the only criterion was that the sequence should branch within a clade containing only members of this taxon with $\geq 95 \%$ UF bootstrap support.

Since no quality-checked reference sequence collection and species-level similarity threshold for EF1A gene sequences of myxomycetes is currently available, four partial EF1A sequences obtained from plasmodia and sclerotia were searched with Nucleotide BLAST online service of GenBank (https://blast.ncbi.nlm.nih.gov/Blast.cgi?PROGRAM=blastn) to roughly determine their taxonomical affinity.

\section{Results}

From 52 samples of myxomycete sclerotia that developed in moist chamber cultures amplification and sequencing of the first part of 18S rRNA gene was successful for 38 samples (73\%), for ten amplification failed and for three samples sequencing yielded an unreadable mixture of sequences. For the 65 plasmodium samples the success rate was lower (53\%), only 35 samples yielded readable sequences. In addition, first part of EF1 gene sequence was successfully obtained from three plasmodium and one sclerotium samples.

Comparisons of 18S rRNA gene sequences with a collection of quality-checked reference sequences with $99.1 \%$ similarity threshold for a species-level classification allowed to annotate 45 sclerotia to species level (Table 2). An exception was made for samples Scl31523, PlsTH87/2, PlsHA53 and PlsTH58/1: although they have less than $99.1 \%$ similarity to their best match, they are reliably placed within a monophyletic cluster containing only sequences of one morphospecies in the phylogeny and can thus be assigned to this species (Fig. 1).

The remaining $2518 \mathrm{~S}$ rDNA sequences obtained from sclerotia and plasmodia which had less than $99.1 \%$ similarity to any reference sequence could be assigned to a genus (15) or an order (10) based on the ML phylogenetic tree (Fig. 1), following the criteria described in Methods section. Another exception from these criteria was made for the sequences Scl31563/1, Scl31577/1, Scl31691/2, Scl31789/1, Scl31791 and Scl31791/2, constituting a cluster of identical sequences with $86.1 \%$ similarity to their best match: they were annotated as Physarum sp. since they were placed within the clade Physarum melleum with 99\% UF bootstrap support.

Four EF1A sequences obtained from three plasmodia and one sclerotium were 92-94\% identical to EF1A gene sequences of myxomycetes from GenBank Nucleotide Database (Table 1). However, we do not offer any hypotheses on their taxonomic affiliation since the intraspecific variability of this genetic marker in myxomycetes is not yet well studied. 
Table 2 Sclerotium ( $\mathrm{Scl}$ ) and plasmodium (Pls) samples used in this study. Sample numbers correspond to the number of moist chamber culture where they originated from. For 18S rRNA gene sequences best matches in an expanded collection of reference sequences from Borg Dahl et al. (2017) and percent of sequence similarity produced by VSEARCH software with a semi-global alignment algorithm are reported, as well as a putative taxonomic position based on sequence similarity and phylogenetic analysis. For EF1A sequences only results of Nucleotide BLAST search are reported (similarity/query cover).

\begin{tabular}{|c|c|c|c|c|}
\hline Sample & GenBank accession & Best match & $\begin{array}{l}\text { Similarity } \\
\%\end{array}$ & $\begin{array}{l}\text { Putative taxonomic } \\
\text { position }\end{array}$ \\
\hline $\begin{array}{l}\text { PIsDN26, PIsHA33, } \\
\text { PIsHA54, PIsHA78, } \\
\text { PIsTH76, PIsTH79, } \\
\text { PIsTH93/2, ScIDN89, } \\
\text { SclTH88 }\end{array}$ & $\begin{array}{l}\text { MG647876, MG647879, } \\
\text { MG647883, MG647886, } \\
\text { MG647899, MG647900, } \\
\text { MG647906, MG647908, } \\
\text { MG647910 }\end{array}$ & Physarum melleum, MG647914 & 99.5 & Physarum melleum \\
\hline PIsHA05 & MG647877 & Physarum melleum, MG647914 & 99.2 & Physarum melleum \\
\hline PlsHA17 & MG647878 & Diderma deplanatum, KM977851 & 92.2 & Physarales \\
\hline $\begin{array}{l}\text { PlsHA37, PlsHA52, } \\
\text { PIsHA55, PIsHA56, } \\
\text { PIsTH39, PlsTH57/2, } \\
\text { PIsTH61/1, PIsTH67, } \\
\text { PIsTH69, PlsTH81, } \\
\text { PIsTH84, PIsTH93/1, } \\
\text { SclHA89 }\end{array}$ & $\begin{array}{l}\text { MG647880, MG647881, } \\
\text { MG647884, MG647885, } \\
\text { MG647887, MG647890, } \\
\text { MG647893, MG647897, } \\
\text { MG647898, MG647901, } \\
\text { MG647902, MG647905, } \\
\text { MG647909 }\end{array}$ & Physarum melleum, MG647914 & 99.7 & Physarum melleum \\
\hline PlsHA53, PlsTH58/1 & MG647882, MG647891 & Physarum melleum, MG647914 & 98.9 & Physarum melleum \\
\hline PIsTH52, PIsTH96 & MG647888, MG647907 & Physarum roseum, HE614605 & 87.6 & Physarales \\
\hline $\begin{array}{l}\text { PIsTH57/1, } \\
\text { PIsTH61/2 }\end{array}$ & MG647889, MG647894 & $\begin{array}{l}\text { Didymium melanospermum, } \\
\text { MG647913 }\end{array}$ & 89.8 & Physarales \\
\hline PlsTH58/2 & MG647892 & Didymium anellus, AM231292 & 97.6 & Didymium sp. \\
\hline PIsTH64, PIsTH87/1 & MG647895, MG647903 & Physarum melleum, MG647914 & 100 & Physarum melleum \\
\hline PlsTH65 & MG647896 & Didymium anellus, AM231292 & 93.2 & Didymium sp. \\
\hline PlsTH87/2 & MG647904 & Physarum melleum, MG647914 & 98.4 & Physarum melleum \\
\hline $\begin{array}{l}\text { Scl31496, Scl31501/5, } \\
\text { Scl31502/1, } \\
\text { Scl31546/4, } \\
\text { Scl31621/3, Scl31748, } \\
\text { Scl31810, Scl32027, } \\
\text { Scl32042 }\end{array}$ & $\begin{array}{l}\text { MG429778, MG429795, } \\
\text { MG429799, MG429803, } \\
\text { MG429804, MG429779, } \\
\text { MG429780, MG429784, } \\
\text { MG429792 }\end{array}$ & Fuligo septica, AJ584697 & 99.7 & Fuligo septica \\
\hline $\begin{array}{l}\text { Scl31519/4, } \\
\text { Scl31582/3, Scl31686 }\end{array}$ & $\begin{array}{l}\text { MG429793, MG429781, } \\
\text { MG429791 }\end{array}$ & Fuligo septica, KM977874 & 100 & Fuligo septica \\
\hline Scl31523 & MG429782 & Fuligo septica, AJ584697 & 98.4 & Fuligo septica \\
\hline Scl31524/3 & MG429783 & Physarum album, LT670002 & 91.7 & Physarum sp. \\
\hline Scl31558/3 & MG429785 & Fuligo septica, AJ584697 & 99.2 & Fuligo septica \\
\hline Scl31560/4 & MG429786 & Diderma niveum, KU198064 & 92.9 & Diderma sp. \\
\hline $\begin{array}{l}\text { Scl31563/1, } \\
\text { Scl31577/1, } \\
\text { Scl31691/2, } \\
\text { Scl31789/1, Scl31791, } \\
\text { Scl31791/2 }\end{array}$ & $\begin{array}{l}\text { MG429797, MG429787, } \\
\text { MG429790, MG429794, } \\
\text { MG429796, MG429798 }\end{array}$ & Physarum melleum, KC759095 & 86.1 & Physarum sp. \\
\hline Scl31565/4 & MG429788 & Physarum album, LT670002 & 91.5 & Physarum sp. \\
\hline Scl31569/4 & MG429789 & Didymium squamulosum, AM231293 & 83.4 & Physarales \\
\hline Scl31902 & MG429800 & Didymium flexuosum, KM977857 & 99.5 & $\begin{array}{l}\text { Didymium } \\
\text { flexuosum }\end{array}$ \\
\hline Scl32002 & MG429801 & Diderma umbilicatum, KP323371 & 93.7 & Diderma sp. \\
\hline Scl32024 & MG429802 & Fuligo septica, AJ584697 & 99.5 & Fuligo septica \\
\hline Scl32058 & MG429805 & Didymium squamulosum, AM231293 & 83.5 & Physarales \\
\hline Scl40262/1 & MG429806 & Badhamia melanospora, KC759108 & 89.3 & Physarales \\
\hline Scl40262/2 & MG429807 & Physarum pseudonotabile, LT670421 & 100 & $\begin{array}{l}\text { Physarum } \\
\text { pseudonotabile }\end{array}$ \\
\hline
\end{tabular}


Table 2 Continued.

\begin{tabular}{lllll}
\hline Sample & GenBank accession & Best match & $\begin{array}{l}\text { Similarity } \\
\text { \% }\end{array}$ & $\begin{array}{l}\text { Putative taxonomic } \\
\text { position }\end{array}$ \\
\hline Scl40297 & MG429808 & Leocarpus fragilis, MG647916 & 96.8 & Leocarpus sp. \\
Scl40361 & MG429809 & Craterium obovatum, KP323369 & 95.6 & Craterium sp. \\
Scl40379 & MG429810 & Didymium squamulosum, AM231293 & 88.3 & Physarales \\
Scl40419 & MG429811 & Didymium trachysporum, MG647912 & 85.6 & Physarales \\
SclTH95 & MG647911 & Physarum melleum, KC759095 & 94.9 & Physarum sp. \\
Pls37171, Scl37174, & EF1A: MG430295, & Diderma pseudotestaceum, KJ676602 & $94 / 98$ & - \\
Pls37495 & MG430297, MG430298 & & & \\
PIs37191 & EF1A: MG430296 & Physarum album, EF513196 & $92 / 100$ & - \\
\hline
\end{tabular}

\section{Discussion}

For 70 of 117 DNA isolates $(60 \%)$ from non-fruiting plasmodia or sclerotia in moist chamber cultures an 18S rRNA barcode was successfully obtained. This result clearly indicates that the multi-copy ribosomal genetic marker used for DNA barcoding in many protists can be easily amplified from trophic and dormant stages of myxomycetes sampled directly from moist chamber cultures. Even a single-copy nuclear gene EF1A can be amplified and sequenced from both plasmodia and sclerotia. Surprisingly, in spite of the fact that usually every moist chamber culture contains a mixture of trophic and dormant stages of different species of myxomycetes, only 3 sclerotium and 19 plasmodium samples showed unclear sequencing chromatograms indicating contamination by DNA of other organisms.

The DNA barcoding approach made it possible to annotate 45 of 70 sequences obtained from sclerotia and plasmodia at species level. This number is surprisingly high because the collection of reference 18S rRNA gene sequences from Borg Dahl et al. (2017) contains sequences of not more than $14 \%$ of the ca. 1000 morphospecies currently accepted (Lado 2005-2017). For an effective application of DNA barcoding for species identification and environmental DNA studies the database of reference sequences should be extended greatly, especially considering the high level of cryptic speciation in myxomycetes (Schnittler et al. 2017b).

Phylogeny-based taxonomical identification of sequences applied in this study proved to be an effective approach for annotating sequences at genus level or higher. The somewhat arbitrary criteria for assignment introduced herein (especially the genus-level similarity threshold) should probably be adjusted in future studies based on larger taxa sampling. In any case, since taxonomical levels are undoubtedly artificial units, it is impossible to choose a perfect genetic similarity threshold that would be adequate in all situations. We think that the analysis of tree topology should be prioritized in ambiguous situations. The prerequisite of the phylogeny-based annotation is a properly rooted tree with a representative set of taxa that includes all the major clades to which the unknown sequences might have an affinity.

Fifteen sclerotia that developed on substrates originating from native oak forests of the Lower Volga River basin (Volga-Akhtuba Bottomland Nature Park and Chapurnikovskaya ravine) were identified as Fuligo septica. Like many taxa forming compound fructifications, this species never or virtually never fruits in moist chamber culture experiments. Interestingly, F. septica is considered as a rare species for the dry steppe and desert areas of the lower Volga River basin, an arid region with a hot and dry continental climate; its fructifications were found only occasionally and mostly in anthropogenic habitats with artificially increased water supply such as gardens or parks (Novozhilov et al. 2006, Zemlyanskaya et al. 2016). Moreover, this species is usually considered associated with leaf litter or deadwood, but all 15 sclerotia developed on pieces of bark of living oak trees. Our results suggest that $F$. septica is much more common for the bottomland deciduous oak forests of the Lower Volga River Basin and for the dry regions of the Caspian Lowland and it has, at least for trophic stages, a wider ecological niche than it was thought previously. 


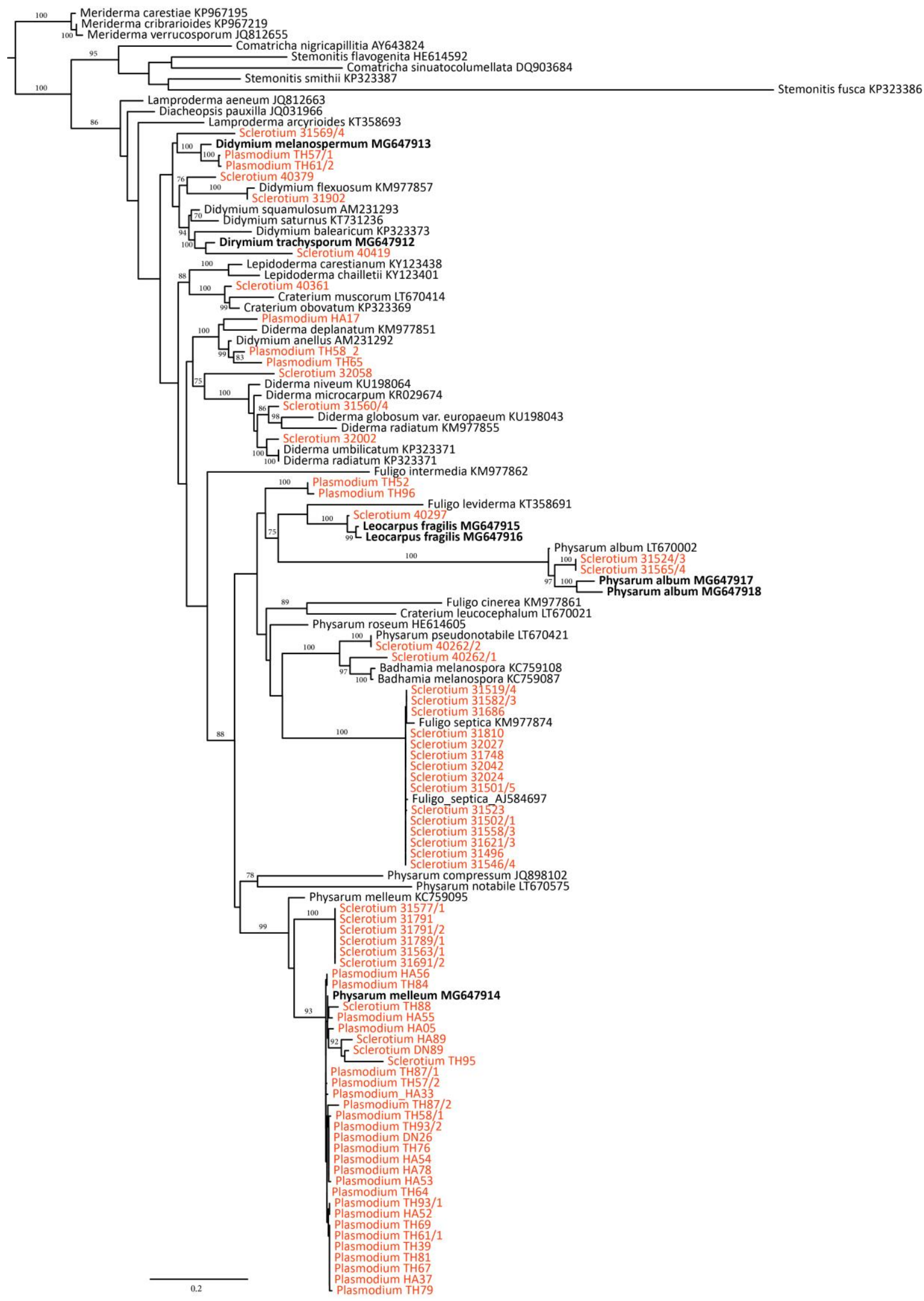

Figure 1 - Maximum likelihood phylogenetic tree for partial 18S rRNA gene sequences obtained from sclerotia and plasmodia that developed in moist chamber cultures (marked with red) together with their best matches from Table 2 and members of major clades of dark-spored myxomycetes retrieved from GenBank. The phylogeny was computed using IQ-Tree under the TNe+I+G4 model with 1000 ultrafast bootstrap replicates. New reference sequences that were not published previously are written in bold. Only UF bootstrap support values $\geq 70 \%$ are shown. 
Another species identified from the sclerotia in this study, Didymium flexuosum, was never reported for the lower Volga River bottomland (Zemlyanskaya et al. 2016). The recently described xerotolerant species Physarum pseudonotabile (Novozhilov et al. 2013), usually readily recovered by moist chamber cultures was identified from sclerotium originating from xerophilous mixed forest near Sudak on Crimea peninsula. This is the first report of P. pseudonotabile for this region, but this finding was not unexpected since the dry climatic conditions and arid Mediterranean plant community type fit the ecological requirements of this xerotolerant species.

Almost $80 \%$ (28 of 36) of plasmodium and sclerotium samples coming from moist chamber cultures with aerial and ground leaf litter from forests of northern Vietnam were identified as Physarum melleum, a species known to inhabit leaf litter from tropical regions. However, sporocarps of this species were recorded only 10 times in a moist chamber- based survey that yielded the plasmodium and sclerotium samples (unpublished data). Moreover, P. melleum constituted only nine records within a five-year survey of myxomycete biota of monsoon tropical forests in southern Vietnam both from field collections and from moist chamber cultures (Novozhilov et al. 2017b). This species seems to fruit only occasionally, staying in plasmodial stage for a prolonged period of time and may thus be underrepresented in sporocarp-based studies.

Three partial EF1A gene sequences of two plasmodia and one sclerotium originating from Bidup-Nui Ba National Park in Vietnam showed 94\% similarity to Diderma pseudotestaceum, a species that was recently described from Cat Tien National Park in Vietnam with sporocarps found on forest leaf litter both in field collections and in moist chamber cultures (Novozhilov et al. 2014). However, we cannot make conclusions on species identity of these plasmodia and sclerotia based solely on EF1A sequences since the level of intraspecific sequence variability is not well-studied for this marker.

An attempt of sequence-based identification of several sclerotia and plasmodia was already made previously (Kamono \& Fukui 2006). It differs from the current study in several aspects: 1) another fragment of the $18 \mathrm{~S}$ rRNA gene was used that does not overlap with sequences in the largest collection of reference sequences of myxomycetes at the moment (Borg Dahl et al. 2017); 2) no criteria for sequence classification were presented and no species-level similarity threshold was used; 3) samples were collected in nature. Thus, the current study offers the first methodological outline to use DNA barcodes as a component of moist chamber culture experiments for identification of plasmodia and sclerotia based on sequence similarity and phylogenetic analysis.

The obtained results suggest that application of DNA barcoding for taxonomic identification of plasmodia and sclerotia that develop in moist chamber cultures can be an effective and promising way to complement classical fruit body-based studies. This approach could extend species lists with taxa that never or rarely fruit in moist chambers and facilitate our understanding of the ecology of such species. Since the sclerotia of myxomycetes represent dry rigid structures, they are easy to isolate, store and handle. Plasmodia are less convenient in handling and to avoid DNA degradation they either should be isolated from moist chambers immediately before DNA extraction or a proper fixation procedure should be developed for their storage. Keeping plasmodia frozen until DNA extraction could probably also be a solution. Our results also suggest that plasmodia tend to yield more noisy sequences, which might be due to presence of diverse microorganisms (including myxamoebae of other myxomycete species) inside the vacuoles of actively feeding plasmodia.

\section{Acknowledgements}

This work was supported by grants from RFBR (Russian Foundation of Basic Research, 1504-07692 A and 15-29-02622 ofi_m) and DFG (German Research Council, RTG 2010). In addition, we acknowledge the use of equipment of the Core Facility Center «Cell and Molecular Technologies in Plant Science» at the Komarov Botanical Institute RAS (St. Petersburg, Russia). A part of this work comes from a small fieldwork and travel grant given by the DAAD (Sustainable Environmental Management Project). 


\section{References}

Borg Dahl M, Brejnrod AD, Unterseher M, Hoppe T et al. 2017 - Genetic barcoding of darkspored myxomycetes (Amoebozoa) - identification, evaluation and application of a sequence similarity threshold for species differentiation in NGS studies. Molecular Ecology Resources doi:101111/1755-099812725.

Camp WG. 1936 - A method of cultivating myxomycete plasmodia. Bulletin of the Torrey Botanical Club 63, 4, 205-210.

Fiore-Donno AM, Kamono A, Meyer M, Schnittler M et al. 2012 - 18S rDNA phylogeny of Lamproderma and allied genera (Stemonitales, Myxomycetes, Amoebozoa). PLoS ONE 7, 4, e35359. doi:10.1371/journal.pone.0035359.

Fiore-Donno AM, Nikolaev SI, Nelson M, Pawlowski J et al. 2010 - Deep phylogeny and evolution of slime moulds (Mycetozoa). Protist 161, 55-70.

Gilbert HC, Martin GW. 1933 - Myxomycetes found on the bark of living trees. University of Iowa Studies in Natural History 15, 3, 3-8.

Hall TA. 1999 - BioEdit: a user-friendly biological sequence alignment editor and analysis program for Windows 95/98/NT. Nucleic Acids Symposium Series 41, 95-98.

Kalyaanamoorthy S, Minh BQ, Wong TKF, von Haeseler A et al. 2017 - ModelFinder: Fast model selection for accurate phylogenetic estimates. Nature Methods 14, 587-589.

Kamono A, Fukui M. 2006 - Rapid PCR-based method for detection and differentiation of Didymiaceae and Physaraceae (myxomycetes) in environmental samples. Journal of Microbiological Methods 67, 496-506.

Katoh K, Rozewicki J, Yamada KD. 2017 - MAFFT online service: multiple sequence alignment, interactive sequence choice and visualization. Briefings in Bioinformatics https://doi.org/10.1093/bib/bbx108.

Lado C. 2005-2017 - An online nomenclatural information system of Eumycetozoa. http://www.eumycetozoa.com/ (accessed 4 December 2017).

Minh BQ, Nguyen MAT, von Haeseler A. 2013 - Ultrafast approximation for phylogenetic bootstrap. Molecular Biology and Evolution 30, 1188-95.

Nguyen LT, Schmidt HA, von Haeseler A, Minh BQ. 2015 - IQ-TREE: A fast and effective stochastic algorithm for estimating maximum likelihood phylogenies. Molecular Biology and Evolution 32, 268-274.

Novozhilov YK, Erastova DA, Shchepin ON, Schnittler M et al. 2017b - Myxomycetes associated with monsoon lowland tropical forests in southern Vietnam. Nova Hedwigia 104, 1-3, 143 182.

Novozhilov YK, Mitchell DW, Okun MV, Shchepin ON. 2014 - New species of Diderma from Vietnam. Mycosphere 5, 554-564.

Novozhilov YK, Okun MV, Erastova DA, Shchepin ON et al. 2013 - Description, culture and phylogenetic position of a new xerotolerant species of Physarum. Mycologia 105, 15351546.

Novozhilov YK, Rollins A, Schnittler M. 2017a - Ecology and distribution of Myxomycetes, In: Myxomycetes: biology, systematics, biogeography and ecology (Eds: S.L. Stephenson \& C.A. Rojas). Academic Press, London.

Novozhilov YK, Zemlyanskaya I, Schnittler M, Stephenson SL. 2006 - Myxomycete diversity and ecology in the arid regions of the Lower Volga River Basin (Russia). Fungal Diversity 23, 193-241.

Rognes T, Flouri T, Nichols B, Quince C et al. 2016 - VSEARCH: a versatile open source tool for metagenomics. PeerJ 4, e2584. doi:10.7717/peerj.2584.

Schnittler M, Dagamac NHA, Novozhilov YK. 2017a - Biogeographical patterns in Myxomycetes. In: Myxomycetes: biology, systematics, biogeography, and ecology (Eds: S.L. Stephenson \& C.A. Rojas). Academic Press, London. 
Schnittler M, Shchepin ON, Dagamac NH, Borg Dahl M et al. 2017b - Barcoding myxomycetes with molecular markers: challenges and opportunities. Nova Hedwigia 104, 1-3, 323-341.

Stephenson SL, Schnittler M, Novozhilov Y. 2008 - Myxomycete diversity and distribution from the fossil record to the present. Biodiversity \& Conservation 17, 285-301.

Zemlyanskaya IV, Smolnyakova YA, Kotelnikova DA, Novozhilov YK. 2016 - Myxomycetes of the Nature Park «Volgo-Akhtuba Bottomland». Micologiya i Phitopatologiya 50, 6, 347-353 (in Russian with English summary). 